Año L. urtea

$126-2018$

Uztaila-abendua Julio-diciembre

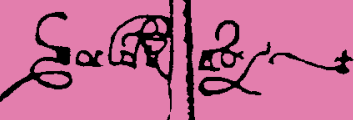
ats
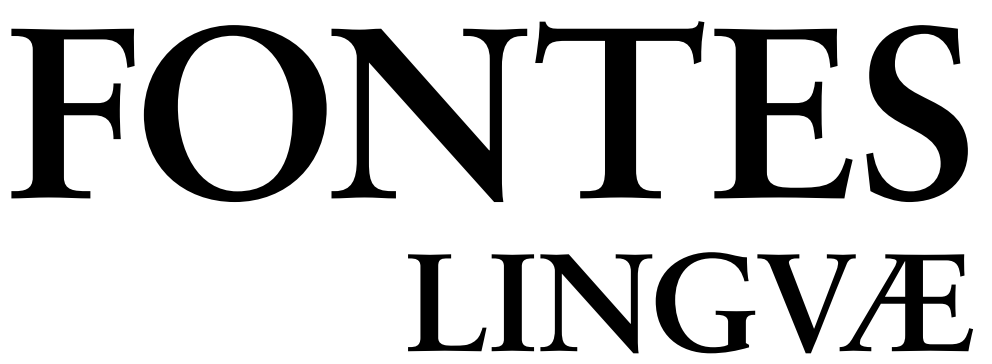

VASCONVM

STVDIA ET DOCVMENTA

SEPARATA

\title{
Word order and syntactic asymmetries in Basque modal constructions
}

Ricardo Etxepare, Myriam Uribe-EtXebarria

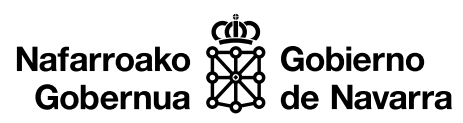

- 00 


\title{
Word order and syntactic asymmetries in Basque modal constructions
}

Hitz hurrenkera eta asimetria sintaktikoak euskararen egitura modaletan

Orden de palabras y asimetrías sintácticas en las construcciones modales del euskara

\author{
Ricardo ETXEPARE \\ IKER CNRS \\ r.etxepare@iker.cnrs.fr \\ Myriam URIBE-ETXEBARRIA \\ University of the Basque Country (UPV/EHU) \\ myriam.uribe-etxebarria@ehu.eus
}

\begin{abstract}
This research was partially funded by the Spanish Ministry of Economy and Competitivity, MINECO [(i) Linguistic Variation and Language Architecture, VALAL FFI2014-53675-P; (ii) Redes de Excelencia Significado $y$ Gramática, SIGGRAM/Grammar \& Meaning network, FFI2016-81750-REDT], the Basque Government (Consolidated Research Groups, HIzkuntzalaritza Teorikorako Taldea, HiTT, code IT769/13), the University of the Basque Country (UFI11/14), and the Agence Nationale de la Recherche, ANR (Basque in the Making, BIM, code ANR-17-CE27-0011-01). It also benefits from funding from the European Seventh Framework Programme for research, technological development and demonstration under grant agreement 613465 . We would like to thank the editors of this issue for giving us the opportunity to contribute to this volume. We also thank two anonymous reviewers for helpful comments and suggestions. We dedicate this paper to Professor Jon Ortiz de Urbina, great linguist and dear friend, whose work has had an enormous impact in the area of Basque linguistics, and in our own research all throughout these years, with our deepest gratitude.
\end{abstract}




\begin{abstract}
This work focuses on a subset of modal constructions in Basque: those involving the necessity modal behar ('need/must'/'have to'). Behar can take either a DP or an uninflected clause as its complement. Uninflected clauses can, in some varieties of Basque, naturally occur preceding or following the predicate. Etxepare and Uribe-Etxebarria (2009) show that the differences in word order correlate with a number of intriguing syntactic asymmetries. In this paper, we extend the relevant observations to include modal stacking, as well as the effect of complement-internal left peripheral elements in the availability of agreement with the matrix auxiliary, which we show to be different for Person and Number agreement.
\end{abstract}

Keywords: modal predicates; need/have to; word order alternations; person vs. number agreement; Basque.

\title{
LABURPENA
}

Behar izenetik eratorritako predikatu modalek izaera desberdineko osagarriak har ditzakete euskaraz, tartean jokatugabeko perpausak. Zenbait hizkeratan jokatugabeko perpaus horiek predikatuaren aurretik zein ondotik ager daitezke. Etxepare eta UribeEtxeberriaren lanaren haritik (2009), erakutsiko dugu jokatugabeko perpausek posizio aldetik erakusten duten aldakortasuna lotua dela asimetria sintaktiko jakingarri zenbaitekin: predikatuaren aurretik edo ondotik agertzeak ondorioak ditu besteak beste komunztaduran, predikatu modalen orden erlatiboan, eta ezker periferiako elementuak predikatu modalaren osagarrian agertzeko posibilitatean.

Gako hitzak: modu predikatuak; behar; hitzorden alternantziak; pertsona vs. zenbaki komunztadura; euskara.

\section{RESUMEN}

Los predicados modales derivados del nombre behar «necesidad» en euskara pueden tomar complementos de tipo nominal o clausal, y entre estos últimos, cláusulas de infinitivo. Estas cláusulas de infinitivo pueden además aparecer por delante o por detrás del predicado modal en algunas variedades del euskara. Etxepare y Uribe-Etxebarria (2009) muestran que estas diferencias en el orden relativo de predicado y complemento clausal dan lugar a una significativa serie de asimetrías sintácticas. En este artículo, extendemos las observaciones realizadas en aquel trabajo incluyendo datos referidos a la cumulación de predicados modales, la disponibilidad de elementos pertenecientes a la periferia izquierda, y las relaciones de concordancia.

Palabras clave: predicados modales; deber/necesitar, alternancias en el orden de palabras; concordancia de persona vs. número; euskara. 
1. THE SYNTACTIC CONFIGURATIONS OF THE BASQUE MODAL PREDICATE BEHAR. 2. THE RELATIVE ORDER OF THE MODAL PREDICATE AND ITS COMPLEMENT. 2.1. The order uninflected clausal complement-modal predicate. 2.2. The order modal predicate-uninflected clausal complement. 3. RELATIVE ORDER, AGREEMENT AND INTERVENTION EFFECTS. 4. PERSON VERSUS Number AGREEMENT. 5. CONCLUSIONS. 6. REFERENCES.

\section{THE SYNTACTIC CONFIGURATIONS OF THE BASQUE MODAL PREDICATE BEHAR ${ }^{1}$}

As illustrated in (1), the modal predicate behar izan ('need'/'must'/'have to') behaves as a regular transitive verb: it takes ergative subjects, nominal complements with absolutive case, and transitive auxiliaries.

$$
\begin{aligned}
& \left(\mathrm{Ni}-\mathrm{k}_{\mathrm{ERG}}\right) \quad \text { [ aldizkari hori ]- } \varnothing_{\mathrm{ABS}} \text { behar dut } \\
& \text { (I-ERG) journal that-ABS need AUX[3sgA-lsgE] } \\
& \text { 'I need that journal' }
\end{aligned}
$$

As is the case with regular transitive clauses, the auxiliary verb in (1) agrees both with the subject and the object of the predicate. Thus, if we change the subject and the object in (1), the auxiliary shows a different agreement pattern, as illustrated in (2) and (3).

$$
\begin{array}{lcll}
\text { Zuek }_{\mathrm{ERG}} & \text { [aldizkari horiek]- } \varnothing_{\text {ABS }} & \text { behar } & \text { dituzue } \\
\text { You(pl) journals those-ABS } & \text { need } & \text { AUX[3plA-2plE] } \\
\text { 'You guys need those journals' } & &
\end{array}
$$

1 In the glosses, E/ERG stands for ergative, A/ABS for absolutive, D/DAT for dative, BEN for beneficiary, GEN for genitive, LOC for locative, ALA for alative, $s g$ for singular, PL for plural, det for determiner, NOM for nominalizer, imp for imperfect, irr for irrealis, INF for infinitival/uninflected clause, SC for small clause and PTC for particle. 
(3)

$$
\begin{aligned}
& \text { Ni-k } k_{\text {ERG }} \text { zu- } \varnothing_{\text {ABS }} \text { behar zaitut } \\
& \text { I-ERG you-ABS need AUX[2sgA-lsgE] } \\
& \text { 'I need you' }
\end{aligned}
$$

Following the general pro-drop character of the language, the arguments of behar izan can be dropped.

$\begin{array}{llll}\text { a. Ni-k } k_{\text {ERG }} \quad \text { [aldizkari horiek]- } \varnothing_{\text {ABS }} & \text { behar ditut } \\ \text { I-ERG journals those-ABS } & \text { need } & \text { AUX[3plA-lsgE] } \\ \text { 'I need those journals' } & & \end{array}$

b. pro $_{\text {ERG }} \quad$ pro $_{\mathrm{ABS}}$ behar ditut

PRO PRO need AUX[3plA-lsgE]

'I need them'

(5) a. $Z u-k_{E R G}$ ni- $\varnothing_{A B S}$ behar nauzu

You-ERG I-ABS need AUX[1.sgA-2sgE]

'You need me'

b. pro $_{\text {ERG }}$ pro $_{\text {ABS }}$ behar nauzu

You-ERG I-ABS need AUX[lsgA-2sgE]

'You need me'

Behar (izan) (henceforth, behar) thus seems to behave as a regular transitive verb.

In addition to nominal complements, the transitive predicate behar can also take uninflected clausal complements ${ }^{2}$ as illustrated in (6), where the infinitival clause precedes the modal predicate.

$$
\begin{aligned}
& \text { (Ane-k) etxe-ra joan behar du } \\
& \text { Ane-ERG house-ALA go need AUx[3sgA-3sgE] } \\
& \text { 'Ane needs to/must/has to go home' }
\end{aligned}
$$

Notice that in (6) behar also functions as a transitive modal verb. Although the verb of the uninflected complement of behar is an unaccusative predicate (joan 'go'), the auxiliary selected in (6) is transitive $(d u)$ and the matrix subject bears ergative case $(-k)$. This is otherwise impossible in Basque. Thus, unless behar is present, the unaccusative verb joan ('go') can never take transitive auxiliaries or ergative subjects, as shown in (7), which is ungrammatical in Basque.

2. In this paper we will use the term clausal in a loose way, as a mere terminological device to distinguish DP complements from complements with a more complex structure and an embedded predicate. For a detailed discussion of the internal structure of the modal complement, see Etxepare and Uribe-Etxebarria (2009, 2012). 


$\begin{array}{llll}(7) * & \text { (Ni-k) } & \text { joan } & \text { dut } \\ & \text { I-ERG } & \text { go } & \text { Aux[3sgA-lsgE] } \\ & \text { 'I have gone' } & \end{array}$

We therefore conclude that in (6) the transitive auxiliary $d u$ is selected by behar, and not by the embedded verb etorri ('come'). We take this as evidence that behar projects its own thematic structure (see Etxepare \& Uribe-Etxebarria, 2012 for details) $)^{3}$.

As shown in (8), in addition to intransitive complements, behar can also take uninflected complements headed by a transitive predicate.

$$
\begin{array}{lllll}
\text { Ni- } k_{\text {ERG }} & \text { liburu-a- } \varnothing_{\text {ABS }} & \text { irakurri } & \text { behar } & \text { dizut } \\
\text { I-ERG } & \text { book-DET-ABS } & \text { read } & \text { need } & \text { AUX[3sgA-2sgD-lsgE] } \\
\text { 'I need/must to read the book to you' } &
\end{array}
$$

Notice that in this case the matrix auxiliary agrees both with the matrix ergative subject (nik ' $\mathrm{I}_{\mathrm{ERG}}$ ') as well as with the embedded arguments (the absolutive complement liburua, 'the book' ${ }_{\mathrm{ABS}}$, and the dative argument $z$ uri ' $\mathrm{yOu}_{\mathrm{DAT}}$ ').

\section{THE RELATIVE ORDER OF THE MODAL PREDICATE AND ITS COMPLEMENT}

Although in all the examples introduced in the previous section where behar takes an uninflected complement this complement precedes behar, clausal complements, unlike DP complements, can naturally occur both preceding and following the modal predicate

3 The modal structure exemplified in (6), where behar behaves as a transitive verb selecting an ergative subject and a transitive auxiliary, coexists and contrasts with an alternative structure, illustrated in (i) below. Note that (i) is parallel to (6), but in this case the subject surfaces with absolutive case and the auxiliary is intransitive.

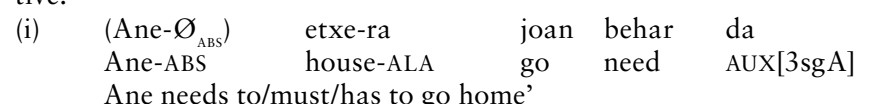

(i) is a case of reanalysis, in which the modal predicate presumably lexicalizes a functional head, and auxiliary selection corresponds to the embedded lexical verb. Balza $(2010,2018)$ analyses these cases as instances of functional restructuring, an analysis that we assume here. In this paper, we leave aside this type of structures and concentrate in those modal structures where behar behaves as a transitive predicate. 
in many Basque varieties ${ }^{4}$. Thus, the modal structure under analysis allows for two different configurations, which we illustrate in (9-10), depending on the relative word order between the modal predicate and its clausal complement.

$\begin{array}{ll}\text { Lehenago etorri behar duzu } & \\ \text { earlier come need } & \text { AUX[3.sgA-2sgE] } \\ \text { 'You must come earlier' } & \\ \text { Behar duzu } & \text { lehenago etorri } \\ \text { need Aux[3sgA-2sgE] } & \text { earlier come } \\ \text { 'You must come earlier' } & \end{array}$

\subsection{The order uninflected clausal complement-modal predicate}

The orders in which the modal complement precedes the modal predicate present properties which are typical of restructuring contexts (see Etxepare \& Uribe-Etxebarria, 2009). Thus, the auxiliary agrees in person and number with all the arguments of the embedded non-finite clause, and this agreement is obligatory, as shown below. Consider (11):

$$
\begin{aligned}
& \left(\mathrm{Zu}-\mathrm{k}_{\mathrm{ERG}}\right) \text { [ horrelako aldizkari-ak]- } \varnothing_{\text {ABS }} \text { erosi behar zenituzke } \\
& \text { You-ERG this-way-GEN journal-DET.PL.-ABS buy need AUX.IRR[3plA-2sgE] } \\
& \text { 'You would need to read books like these' }
\end{aligned}
$$

In (11) the auxiliary verb zenituzke shows agreement both with the ergative subject (zuk 'you') and the absolutive DP (aldizkariak 'journals'), the complement of erosi 'to buy'. As shown in (12a), if we add a third argument, like a dative DP (an argument of the embedded predicate), the main auxiliary also has to agree with it. If the auxiliary fails to agree with any of the embedded arguments, the result is ungrammatical, as illustrated in (12b-c).

4 The varieties that we take into consideration here correspond roughly to the area encompassing Irun, Errenteria and Oiartzun (see also Balza, 2018). These are not the only varieties in which sequences like (10) are possible. Such sequences are also frequent in Eastern varieties, for instance. But in the relevant speech of this area, the rightward construction of modal predicates is one among many others, which are not necessarily associated with modality. As shown by Haddican (2005) for instance, it is typical of Oiartzun Basque to have rightward constructions with a dummy egin 'do', which are reminiscent of the modal constructions in the sense that they also seem to project an independent predicate. In these varieties, sequences like (ia,b) coexist with the ones in (10):

(i) a. Jon in da berandu etorri

Jon done Aux[3sgA] late arrive

'Jon arrived late'

b. Jone-k in du berandu etorri

Jon-ERG done AUX[3sgA-3sgE] late come

'Jon arrived late'

This may be a relevant fact when we compare the data here with data coming from other varieties in which surface sequences like (10) are also possible. See Balza (2018) for corpus related data on this issue. For a sample of the Basque of Irun see Alzola (1994). We will not address here the issue of why uninflected complements to the right and to the left of the modal predicate can have different sizes and involve different structures. Also, although the uninflected clausal complements to the right of the modal predicates are usually interpreted as involving focalization, here we will leave aside many issues concerning information structure. For related discussion on word order and modals, see Etxepare and Haddican (2017). 


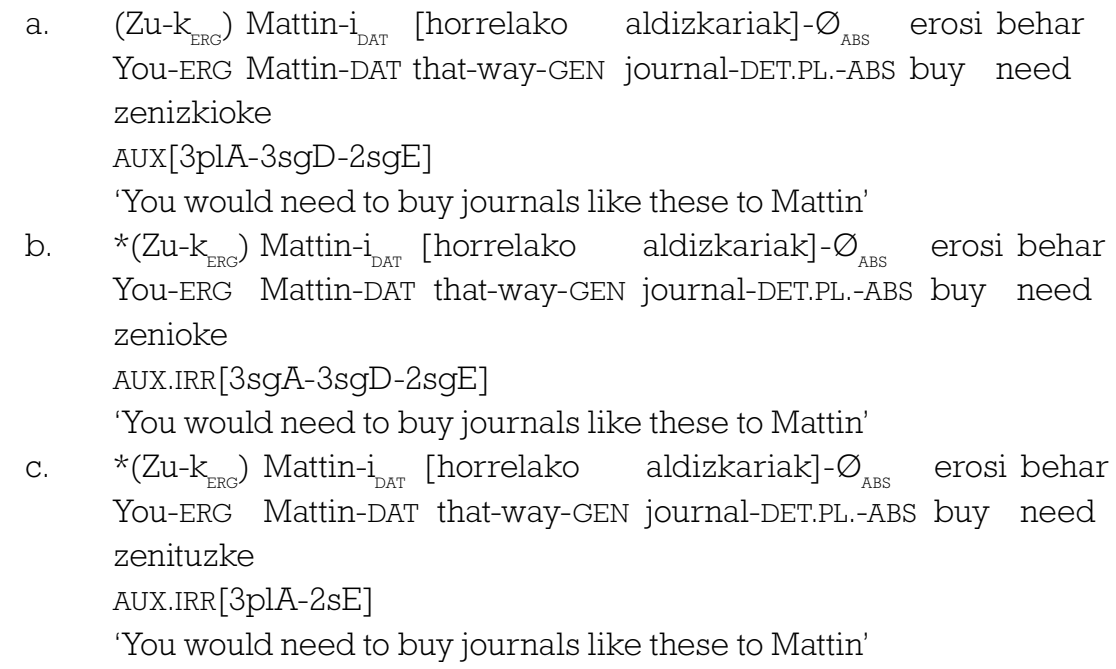

(12b) is bad because the main auxiliary doesn't show number agreement with the embedded object (the form zenioke shows singular agreement with the embedded object, which is plural and not singular). (12c) is bad because the form zenituzke does not show agreement with the embedded dative.

As we would expect from restructuring configurations, this configuration does not admit an independent temporal modifier in the embedded complement. In (13a) the adverb atzo ('yesterday') modifies behar: the need is thus located in the temporal span that corresponds to yesterday. As soon as we add a temporal modifier in the embedded complement, the sentence becomes ungrammatical, as shown in (13b), where we have added the adverb gaur ('today').
a. Jone-k atzo etxe-an egon behar zuen
Jone-ERG yesterday home-LOC be need AUX.PAST[3.sgA-3sgE] 'Jon had to/needed to be home yesterday'
b. *Jone-k atzo gaur etxe-an egon behar zuen Jone-ERG yesterday today house-LOC be need AUX.PAST[3.sgA-3sgE] 'Yesterday Jon had to/needed to be home today'

One could argue that the ungrammaticality of (13b) is based on a semantic restriction: the incompatibility of licensing the two adverbials 'yesterday' and 'today' in the same sentence. However, as we will show in the next section, the constraint must be syntactic, as the double adverbial modification is possible when the embedded uninflected «clause» surfaces following, instead of preceding, behar. The problem is not adjacency either, as topicalizing one of the adverbs for instance, does not improve the sentence:

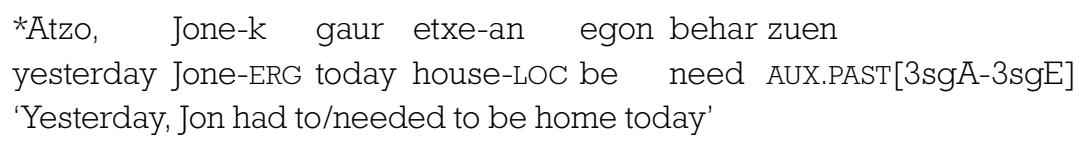


Complement-modal configurations do not license negation in the embedded complement either. Thus, while a negative embedded complement is possible in other languages, as illustrated by the Spanish and English modal sentences in (15), its Basque counterpart in (16) is totally ungrammatical.
a.
$\begin{array}{lllllll}\text { Debes } & \text { no } & \text { quedar-te } & \text { en } & \text { casa } & \text { tanto } & \text { tiempo } \\ \text { must-you } & \text { neg } & \text { stay-CL } & \text { at } & \text { house } & \text { so } & \text { long }\end{array}$
'You must not stay at home for such a long time'
b. You must not stay at home alone
(16) a. * Zu-k [etxe-an ez geratu] behar duzu
You-ERG home-LOC NEG stay need AUX[3sgA-2sgE]
'You must not stay at home'
b. * Zuk [ez etxe-an geratu] behar duzu
c. * Zuk [etxe-an geratu ez] behar duzu

As shown by Irurtzun (2007), focus can be independently licensed in non-finite domains in Basque. In that case, and unlike what happens in finite clauses, adjacency between the focalized element and the verb is not required (from Irurtzun, 2007, p. 163):
A: $\quad[$ Kepa-k ardoa eda-te-a $]-\varnothing_{\text {ABS }}$ arraroa da
[Kepa-ERG wine drink-NOM-DET]- $\varnothing_{\text {ABS }}$ strange AUX[3.sgA]
'It is a strange thing for Kepa to drink wine'
B: $E z,\left[J U L E N E-K\right.$ ardoa eda-te-a] $-\varnothing_{\text {ABS }}$ da gauza arraroa
No, [Julene-ERG wine drink-NOM-DET] AUX[3.sgA] thing strange
'No, it is a strange thing for JULENE to drink wine'

The modal construction under analysis does not license focalization within the embedded complement. Compare (18a), an informationally neutral sentence, with (18b), which has focus on the indirect object Elenari 'to Elena':

(18) a. (Gu-k) [Andoni-ri opariak- $\varnothing$ eman ] behar dizkiogu

We-ERG [ Andoni-DAT books-ABS give need AUx[3plA-3sgD-lplE]

'We need to give the presents to Andoni'

b. *(Gu-k) [ELENA-RI opariak- $\varnothing$ eman] behar dizkiogu

We-ERG [Elena-DAT books-ABS give need AUX[3plA-3sgD-lplE]

'We need to give the books to Elena'

Finally, complement-modal configurations present restrictions in modal stacking. Thus, we take (19b) to be sensibly worst than (19a):

(19) a. Erosi nahi izan behar dugu

buy want be need we.have

'We need to wish to buy it'

b. *Erosi behar izan nahi dugu

buy need be want we.have

'We wish to need to buy it' 
(19) raises the question of why modal stacking is impossible in (19b) but possible in (19a). Assuming the problem is not semantic (witness the fact that the English translations are perfectly interpretable), a possible answer comes from Cinque's hierarchy of functional projections, in which necessity modals are shown to occur in a position hierarchically higher than volitional modals (Cinque, 1999, p. 106).

$$
\begin{aligned}
& \text { MoodPspeech act }>\text { MoodPevaluative }>\text { MoodPevidential }>\text { ModPepistemic } \\
& >\text { TP(Past) }>\text { TP(Future) }>\text { MoodPirrealis }>\text { ModPalethic }>\text { ModPnecessity } \\
& >\text { ModPpossibility AspPhabitual }>\text { AspPdispdispositional }>\text { AspPrepetitive }(I) \\
& >\text { AspPfrequentative }(I)>\text { ModPvolitional }>\text { AspPcelerative }(I)>\text { TP(Anterior) } \\
& >\text { AspPterminative }>\text { AspPcontinuative }>\text { AspPretrospective }>\text { AspPproxima- } \\
& \text { tive }>\text { AspPdurative }>\text { AspPgeneric/progressive }>\text { AspPprospective }>\text { ModP } \\
& \text { obligation }>\text { ModPpermission/ability }>\text { AspPcompletive }>\text { VoiceP }>\text { Asp- } \\
& \text { Pcelerative }(I I)>\text { AspPrepetitive }(I I)>\text { AspPfrequentative }(I) ~
\end{aligned}
$$

If modal stacking obeys a hierarchy such as the one in (20), we expect the relative order of possibility modals and necessity modals to be fixed too. Necessity modals should dominate possibility modals. This is what we find in Basque, as shown in (21):

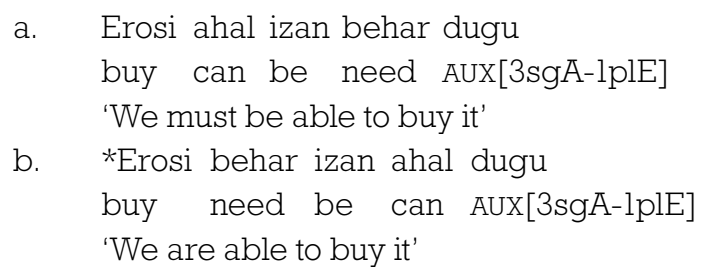

Finally, by transitivity, we expect that volitional modals will necessarily be below both possibility and necessity modals, as is the case. Any order in which the volitional verb follows either the possibility modal or the necessity modal is impossible:

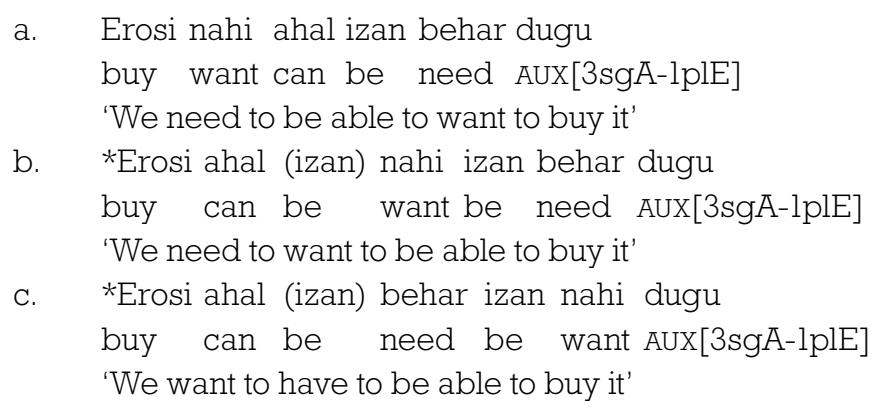

Co-occurrence restrictions in modal sequences follow naturally from an expanded Cinquean hierarchy under the assumption that modal verbs are functional heads. But we have seen that Basque necessity and volitional modals do not seem to fall under this category, witness the transitive status of the necessity modal in cases in which the embedded predicate is unaccusative (cfr. ex. (6), (9) and (10)). The modal predicate nabi izan 'to want' behaves as necessity modals in this regard: 


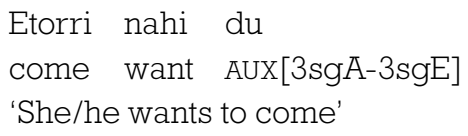

How can we reconcile the transitivity of the modal predicate and the stacking restrictions? In this paper we will only sketch a possible approach. Etxepare and UribeEtxebarria (2012) propose the following underlying structure for denominal modal constructions: for them, the relation between the modal behar and its complement is one that involves a predication relation. Thus, the structure underlying an example like (24a) involves a small clause in which behar is the predicate and the clausal complement is the subject. This small clause is selected by a benefactive adposition, which takes the subject of the clause as its external argument. The construction can be intuitively paraphrased as «coming is a necessity for the subject». The adpositional phrase is selected by an intransitive copula, which we characterize as $\mathrm{BE}$ :

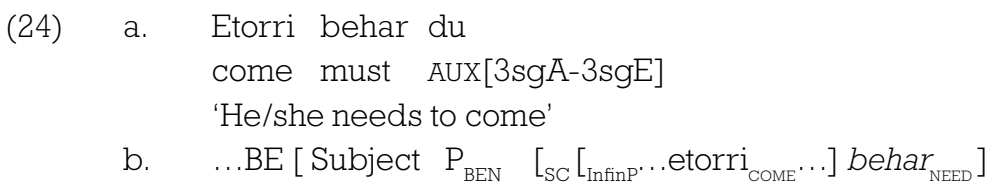

The analysis is inspired by Harves and Kayne's (2012) analysis of need-type denominal modals in English, which also involves an independent nominal predicate need. Unlike in Harves and Kayne's analysis though, in Etxepare and Uribe-Etxebarria's analysis of the Basque denominal necessity modal, the noun behar does not incorporate into the higher copula. The structure in $(24 \mathrm{~b})$ is reminiscent of the modal configurations one can observe in Celtic languages like Irish Gaelic (25a), from Hansen and De Haan, 2009), or Breton (25b), (from Kerrain, 2010, p. 79, apud Arbres, see Etxepare and Uribe-Etxebarria, 2012). In Celtic languages, the nominal predicate expressing necessity occurs right after the finite copula, a position typically reserved to predicates in existential constructions, and the subject of the modal predicate is independently introduced by a benefactive preposition:

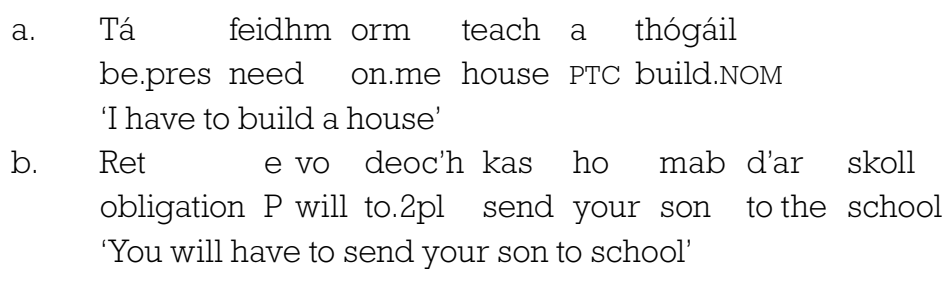

In Basque, the benefactive adposition incorporates into the silent copula BE, and this is at the origin of the transitive auxiliary employed in these constructions. In other words, transitivity is not directly related to behar, but to the adpositional structure that dominates the predication relation between behar and the non-finite clause. Since behar does not incorporate, it is free to raise into some functional projection in the higher clause. This functional projection could correspond to Cinque's necessity modal projection in the case of behar: 


$$
\left[_{\text {MoodNec }} \text { behar Mood } \ldots \text {...BE }+\mathrm{P}\left[\text { Subject }\left(\mathrm{P}_{\mathrm{BEN}}\right)\left[_{\mathrm{SC}}\left[{ }_{\text {Infinp }} \ldots \text { etorri.... }\right](\text { behar })\right]\right]\right]
$$

From that position, the necessity modal c-commands the rest of the verbal structure, including other modals that can be embedded in the non-finite clause:

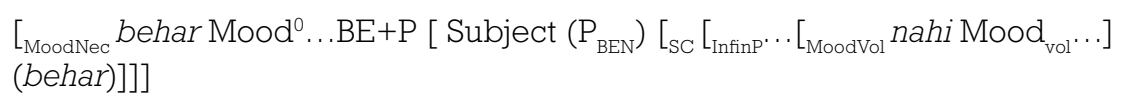

The configuration in (27) obeys Cinque's hierarchy, which concerns functional heads. Thus, it is not the direct relation between the noun behar and the embedded volitional modal that matters, but rather the scope relation between the higher modal head and the embedded modal head that hosts the volitional noun nabi 'wish'. The same goes for the relative order of possibility and necessity modals.

\subsection{The order modal predicate-uninflected clausal complement}

The modal structures with the word order behar-infinitival complement present important differences when compared to those analyzed in the previous section, where the modal predicate follows its infinitival complement. Etxepare and Uribe-Etxebarria (2009) note, for instance, that number agreement becomes optional when the infinitival follows the modal. Compare in this regard the examples in $(28 \mathrm{a}, \mathrm{b})$, in which the clausal complement follows the modal, and in which both singular and plural agreement with the embedded object are possible, with $(29 \mathrm{a}, \mathrm{b})$, where the infinitival complement precedes the modal predicate. Within the latter pair of sentences, only the one displaying number agreement with the object is grammatical (29b).

$$
\begin{aligned}
& \text { a. }\left(\mathrm{Ni}-\mathrm{k}_{\mathrm{ERG}}\right) \text { behar nuke [ [horrelako-ak]- } \varnothing_{\mathrm{ABS}} \text { maizago ikusi] } \\
& \text { I-ERG need AUX.IRR[3.sgA-1.sgE] such-DET.PL.-ABS more.often see } \\
& \text { 'I would need/would have to see things like that more often' } \\
& \text { b. }\left(\mathrm{Ni}-\mathrm{k}_{\mathrm{ERG}}\right) \text { behar nituzke [ [horrelako-ak]- } \varnothing_{\mathrm{ABS}} \text { maizago ikusi] } \\
& \text { I-ERG need AUX.IRR[3plA-lsgE] such-DET.PL.-ABS more.often see } \\
& \text { 'I would need/would have to see things like that more often' } \\
& \text { (29) a. *(Ni-k } \left.\mathrm{ERG}_{\mathrm{ES}}\right)\left[\text { horrelako-ak]- } \varnothing_{\mathrm{ABS}}\right. \text { maizago ikusi] behar nuke } \\
& \text { I-ERG SUCh-DET.PL-ABS more.often see need AUX.IRR[3.sgA-lsgE] } \\
& \text { b. }\left(\mathrm{Ni}-\mathrm{k}_{\mathrm{ERG}}\right) \text { [ [horrelako-ak]- } \varnothing_{\mathrm{ABS}} \text { maizago ikusi] behar nituzke } \\
& \text { I-ERG such-DET.PL-ABS more.often see need AUX.IRR[3plA-lsgE] }
\end{aligned}
$$

Besides inducing optional agreement, the modal structure where behar precedes its clausal complement also allows for embedded temporal modification (30), as well as for the occurrence of left peripheral elements such as negation or focus in the infinitival dependent (31)-(32):

$$
\begin{aligned}
& \text { Jone-k atzo behar zuen } \quad \text { [gaur etxe-an egon] } \\
& \text { Jone-ERG yesterday need AUX.PAST[3sgA-3sgE] today house.LOC be } \\
& \text { 'Jon needed yesterday to be at home today' }
\end{aligned}
$$




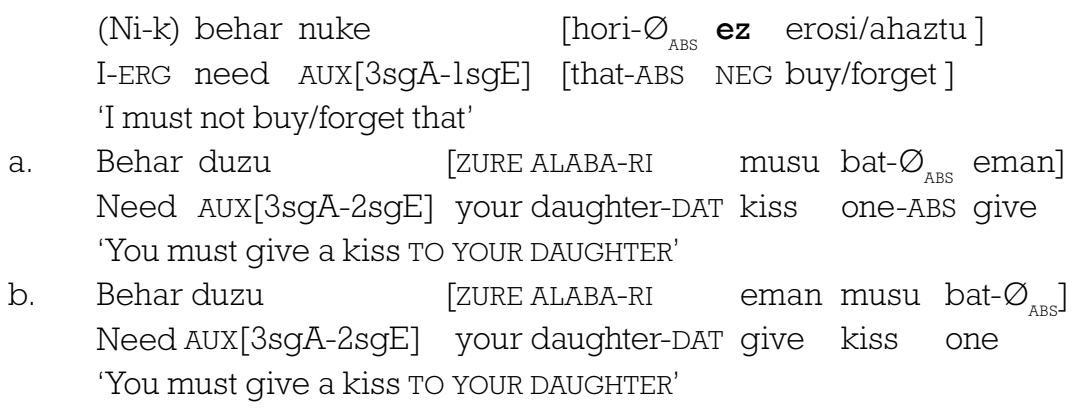

Note that, as in nominalized clauses, adjacency between the focus and the predicate is not required in (32), with the order modal predicate-infinitival. The negation occurring in (31) is bona fide clausal negation, not constituent negation. This negation for instance, can license n-words in Basque, as shown in (33):

$$
\begin{aligned}
& \text { (Ni-k) behar nuke [deus- } \varnothing_{\text {ABS }} \text { (ere) ez erosi] } \\
& \text { I-ERG need AUX.IRR[3.sgA-lsgE] anything-ABS even NEG buy } \\
& \text { erosteko adikzio honetatik libratzeko } \\
& \text { buy.NOM.for addiction this.from free.NOM.for } \\
& \text { 'I should not buy anything (in order to get rid forever of this addiction to } \\
& \text { shopping)' }
\end{aligned}
$$

Finally, the presence of a rightward dependent can result in sequences which are not allowed in leftward modal stacking. For instance, volitional predicates can dominate necessity modals, when the latter occurs to the right:

$$
\begin{aligned}
& \text { a. *Erosi behar izan nahi luke } \\
& \text { buy need be want Aux.IRR[3sgA-3sgE] } \\
& \text { 'He/she wants to need to buy it' } \\
& \text { b. Nahi luke erosi behar izan } \\
& \text { want AuX.IRR[3sgA-3sgE] buy need be } \\
& \text { 'He/she wants to need to buy it' }
\end{aligned}
$$

Word order alternations have no effect in the admissibility of possibility>necessity scope relations, suggesting this is a semantic restriction, not a syntactic one (see Ramchand and Svenonius, 2014, for a critical assessment of Cinque's hierarchy as a purely syntactic one $)^{5}$ :

5 A search in Google for the English sequence able to have to yields not a single example. The English translation corresponds to an impossible sentence in English too. 


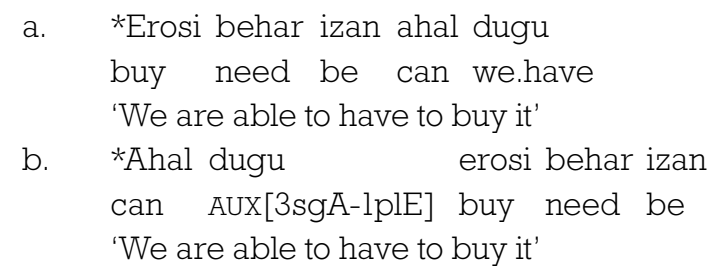

What makes rightward branching special for co-occurrence restrictions? We will not go into the precise structure underlying the rightward cases, but we just note that in Cinque's approach, modal stacking follows from the rigid ordering of functional heads in the clausal structure. For this, modal predicates must be part of a single functional domain. In other words, ordering restrictions in modal sequences are a signature of monoclausality. A possibility therefore, is that modal sequences that involve rightward dependents are bi-clausal, and therefore correspond to different functional domains. In other words, their relative order is irrelevant in that case.

\section{RELATIVE ORDER, AGREEMENT AND INTERVENTION EFFECTS}

How should we interpret the apparent optionality of agreement when the modal precedes the infinitival? Etxepare and Uribe-Etxebarria (2009) propose that the apparent optionality arises as a consequence of locality restrictions. We have seen that rightward infinitival dependents may show a level of structural complexity that is not available to leftward dependents. Infinitival-internal focus operators, negation or temporal modification arise only when the infinitival follows the modal predicate, not otherwise. Agree (Chomsky, 2001) is an operation that obeys locality restrictions, either of the cyclic sort (phasal locality), or of the relative sort (intervention). If rightward infinitivals can be structurally more complex than leftward ones involving a biclausal structure, it is possible that the optionality of agreement is actually due to the presence of a structural configuration that does not allow Agree to apply. That structural factors are at play was shown by Etxepare and Uribe-Etxebarria (2009) in the context of negation. Consider the following apparent case of optionality of agreement:



Etxepare and Uribe-Etxebarria (2009) note that the optionality disappears if negation intervenes:

\footnotetext{
a. * Behar nituzke

ez guraso-ak- $\varnothing_{\text {ABS }}$ hain maiz ikusi

need AUX.IRR[3plA-lsgE] NEG parents-ABS that often see

'I should not see my parents that often'
} 


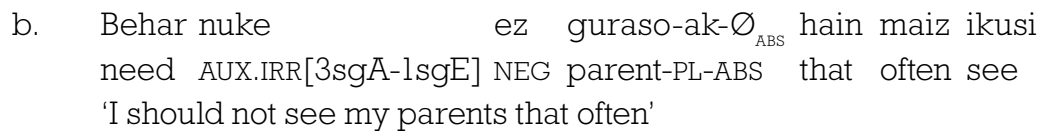

Balza (2018) on the other hand observes that the relative scope of the focus and the modal predicate in modal constructions is sensitive to the word order alternation. A sentence such as (38) in Basque is ambiguous between two possible readings:

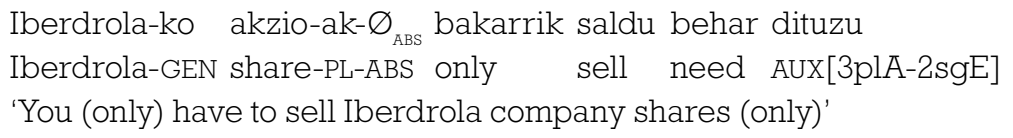

In the first reading, the only thing that you need to do is to sell Iberdrola company shares. In the second reading, what you must do is to sell those shares and those shares only. So under the first reading, if together with Iberdrola shares you sell other shares, it will be an unnecessary but permissible step. A follow up sentence such as (39) is possible under that reading:

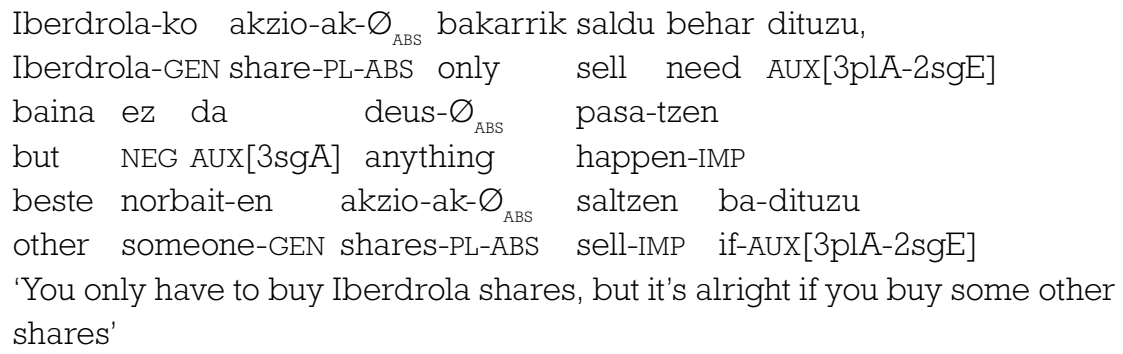

Under the second reading, a continuation like the one in (39) is not possible. Modal-complement orders allow us to isolate the second reading. Consider for instance the following minimal pair, involving a rightward non-finite dependent:

$\begin{array}{lllll}\text { a. } & \text { Behar dituzu } & \text { Iberdrola-ko } & \text { akzio-ak-- } \varnothing_{\text {ABS }} & \text { bakarrik saldu } \\ \text { need AUX[3plA-2sgE] } & \text { Iberdrola-GEN } & \text { share-PL-ABS } & \text { only } & \text { sell } \\ \text { 'You (only) have to sell Iberdrola shares (only)' } & & \\ \text { b. } & \text { Behar duzu } & \text { Iberdrola-ko } & \text { akzio-ak-- } \varnothing_{\text {ABS }} \text { bakarrik saldu } \\ \text { need AUX[3sgA-2sgE] Iberdrola-GEN share-PL-ABS } & \text { only } & \text { sell } \\ \text { 'You have to sell Iberdrola shares only' } & & & \end{array}$

(40a), which shows agreement with the embedded object, allows the same readings as the restructuring configuration in (39). (40b), with lacks the plural number agreement affix, only allows narrow scope for the shares. This is why the same continuation that is possible in (39) sounds pragmatically odd in this case:

$$
\begin{array}{llll}
\text { Behar duzu } & \text { Iberdrola-ko akzio-ak-- } \varnothing_{\text {ABS }} & \text { bakarrik saldu } \\
\text { Need } & \text { AUX[3sgA-2sgE] } & \text { Iberdrola-GEN share-PL-ABS only sell }
\end{array}
$$




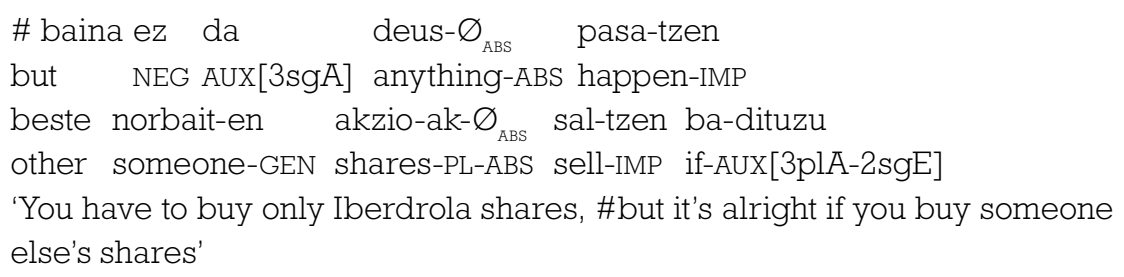

Why should this be so? Why the interaction between scope and agreement?

Etxepare and Uribe-Etxebarria (2008) argue in the context of pairs such as (42a,b) that focus operators can occupy two syntactic positions in the clause structure: one in the vicinity of the $\mathrm{vP}$, and one dominating TP. The two positions become directly observable in the context of negative sentences:

(42) a. LIBURU-A- $\varnothing_{\text {ABS }}$ ez du Jone-k liburutegi-ra itzuli
Book-the-ABS NEG AUX[3plA-2sgE] Jone-ERG library-ALA returned
'It is the book that Jon has not returned to the library'
b. Jone-k ez du LIBURU-A- $\varnothing_{\text {ABS }}$ itzuli liburutegi-ra
Jon.erg NEG has book-the-ABS returned library-ALA

Note that in (42b), where the focus follows the finite auxiliary, the focus position cannot be in-situ, as it precedes the Postpositional Phrase liburutegira «to the library», unlike in $(42 a)^{6}$. If Etxepare and Uribe-Etxebarria are right in claiming that in addition to a high focus position there is an additional focus position that can be internal to the TP (see also Belletti, 2005), then the position of the only-phrases in (40a,b) becomes ambiguous. They could lie in the vicinity of the vP, or they could occupy a focus position higher than TP. What would the eventual consequences of such a choice be in the context of agreement? In the case in which the focus occupies a position in the vicinity of the $\mathrm{vP}$, there is no reason to claim the presence of an independent $T$ in the embedded complement. But if there is no intervening T, the only syntactic Probe that can reach for agreement features is the highest $\mathrm{T}$, the one corresponding to the matrix clause. If this is the case, we expect agreement to manifest in the auxiliary. This option would correspond to (40a), with the underlying structure in (43a). In (43a), the embedded focus position dominates the vP. There is no embedded T, and the object sits in the lowest Focus Phrase. Since there is no $\mathrm{T}$ within the infinitival complement, there is no intervening Probe, and the matrix $\mathrm{T}$ (the finite auxiliary) can probe for Number features in the embedded clause, reaching the focalised object. In (43b), $T$ is present in the embedded complement, and intervenes in the Agree operation, as a closer Probe. The result is an intervention effect.

6 An alternative analysis would have the focus in-situ with the postpositional phrase in some right adjoined or right dislocated position, as in Arregi (2001). We don't think however that the intonational contour of the sentence requires any pause between the lexical verb and the postpositional phrase. For a criticism of the generalized use of the right dislocation option as a means to explain the adjacency between focus operators and lexical or finite verbs, see Irurtzun (2007). 


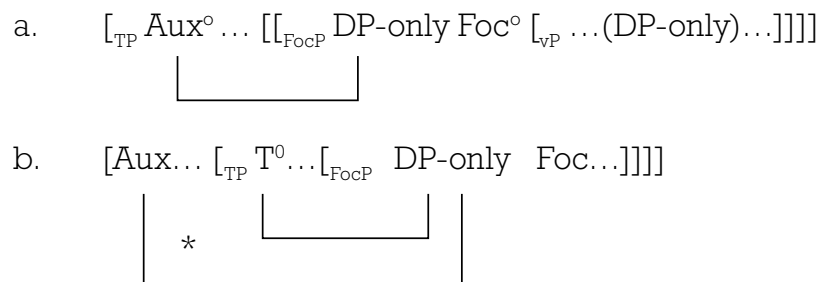

(Agree)

(Agree)

The intervention effect accounts in a simple way for the apparent optionality of agreement. But why should agreement correlate with ambiguous relative scope? In Etxepare and Uribe-Etxebarria's (2012) account of the underlying structure of denominal modals in Basque, the nominal behar and the non-finite clause constitute a Small Clause. Assuming an asymmetric structure for Small Clauses, (as in Den Dikken, 2006), in which a Relator links the two terms of the predication relation, the focus feature will c-command the predicate behar and therefore the original merging position of the modal noun will be one that allows the relative scope focus $>$ modal:

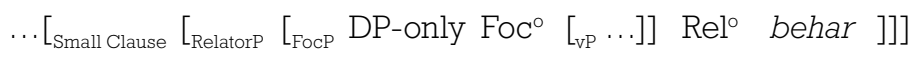

If as suggested by Moro (2001) and Chomsky (2013), among others, the Small Clause corresponds to a symmetric configuration, then the subject and the predicate will c-command each other, and the original position will allow for both readings:

$$
\left.\cdots\left[_{\text {Small Clause }}\left[{ }_{\text {FocP }} \text { DP-only Foc }{ }^{0}\left[{ }_{\mathrm{vP}} \cdots\right] \text { behar }\right]\right]\right]
$$

Let us come back to the negation cases. Etxepare and Uribe-Etxebarria (2009) note, as illustrated in $(37 \mathrm{a})$ that negation blocks agreement with the embedded object when it intervenes between the matrix auxiliary and the embedded object. We repeat the relevant example below:

$$
\begin{aligned}
& \text { *Behar nituzke ez guraso-ak- } \varnothing_{\text {ABS }} \text { hain maiz ikusi } \\
& \text { need AUX.IRR[3plA.lsgE] NEG parents-ABS that often see } \\
& \text { 'I should not see my parents that often' }
\end{aligned}
$$

Although negation is known to intervene in phenomena involving Agree, as in pseudopassives (47a), or in Clitic Climbing (47b), it is not evident why it should be so.

$$
\begin{aligned}
& \text { a. Se necesitan (*no) cerrar acuerdos rápidamente } \\
& \text { CL need.3PL NEG close agreements rapidly } \\
& \text { 'It is required that agreements (not) be closed rapidly' } \\
& \text { b. Lo quiere (??no) comprar } \\
& \text { CL want.3SG NEG buy.INF } \\
& \text { 'He wants (not) to buy it' }
\end{aligned}
$$

From a Relativized Minimality perspective, the blocking effect of negation is unexpected. It does not have the relevant features that would impede establishing a link 
between the clitic or the object Goal and the Probe. One possibility that we would like to explore is that the presence of negation may imply the presence of other functional elements that can stand in the way of Agree. In Laka's (1990) classical analysis of sentential negation in Basque, the presence of clausal negation implies a temporal projection. Laka argues that negation in Basque, or to be more precise, a functional head that hosts not only negation, but also emphatic affirmation and in some dialects foci, dominates the IP. She calls this projection Sigma Phrase. The structural position of Sigma becomes manifest for instance in IP-ellipsis, which leaves negation untouched in Basque:

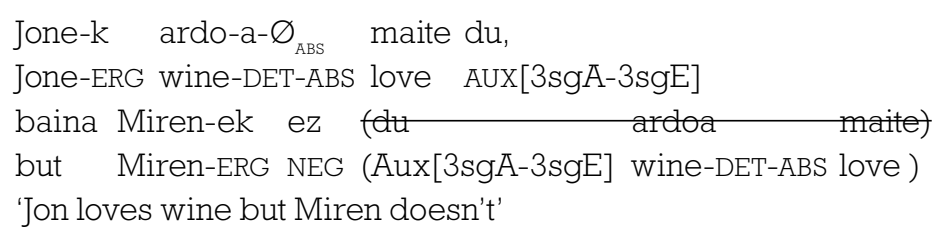

On the other hand, Haddican $(2004,2005,2008)$ argues that negation in Basque, $e z$, is not originally merged in its surface position, but rather raises to that position from (the specifier of ) a lower NegP in the vicinity of the vP:

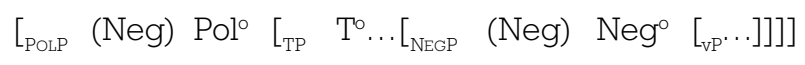

The low position of negation in Basque shows up overtly in some dialects, which allow post-auxiliary negation (see recently Etxepare, 2016):

$$
\begin{aligned}
& \text { Jon-ek du ez deus erosi } \\
& \text { Jon-ERG has not anything-ABS bought } \\
& \text { 'It is Jon who didn't buy anything' }
\end{aligned}
$$

Under Haddican's analysis, which we assume here, the negation particle can actually occupy two positions: one in the vicinity of the vP, and another one in a left peripheral Polarity head. The latter implies the presence of T. In fact, the relevant configurations are similar to what we concluded for focus $(c f r$. 43). If the focus position is the highest one, then there is an intervening $\mathrm{T}$, and therefore the matrix $\mathrm{T}$ cannot reach into the embedded object Goal. If the negation is the lower one, the one that occupies a position in the vicinity of the verbal phrase, then $\mathrm{T}$ does not need to be present. In those cases, the matrix T can Agree with the embedded object. The two structures are represented in $(51 \mathrm{a}, \mathrm{b})$.

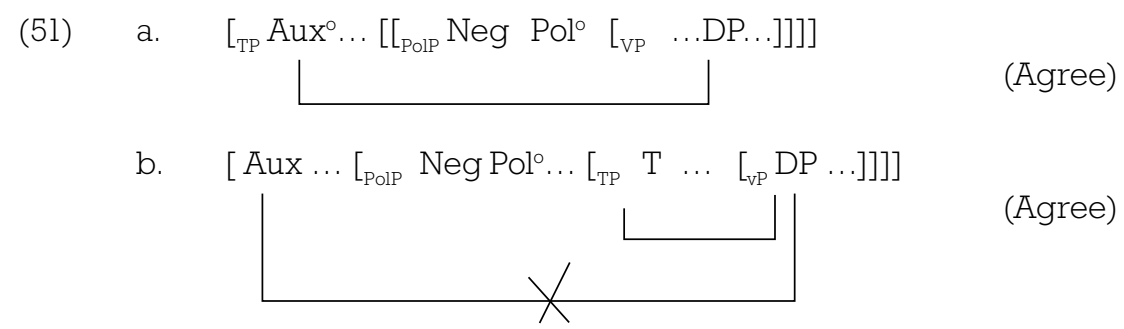


That the presence of T may be relevant is shown by the fact that independent temporal modification in the embedded infinitival has the same effect, blocking agreement with the embedded object:



Notice that the blocking effect of an intervening negation can be circumvented if the object moves to a position higher than negation, as shown by the contrast between (53a), where the embedded complement follows negation, and (53b), where it precedes the negative head as a result of syntactic movement. Compare also (53c) and (53d), involving focalization (syntactic movement) of the embedded complement to the matrix high focus position.

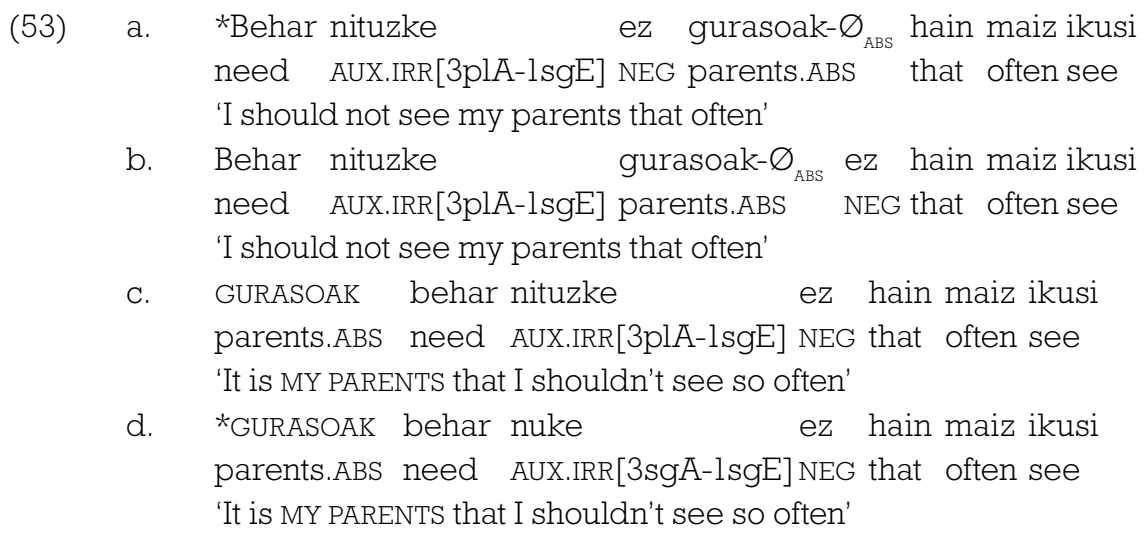

As the contrast in (53c-d) shows, movement of the embedded complement out of the embedded domain to the matrix focus position triggers obligatory number agreement with the matrix auxiliary.

Why should the position of the object in all these examples make a difference? Let us consider (53a-b) first. In our terms, the position of the object in these cases is one that circumvents the embedded T. Negation in PolP dominates T in Basque, and therefore an element that sits in the Spec of Polarity Phrase (or in a higher position) is outside the minimal domain of T. In other words, configurations such as (54) are perfectly possible:

$$
\text { [ Aux... [PoLP DP Neg } \left.\left.\left.\left.{ }_{\text {TPP }} \text { (DP) } \mathrm{T}^{\circ} \ldots(\mathrm{DP}) \ldots\right]\right]\right]\right]
$$


With the DP outside the minimal domain of T, there is nothing that intervenes between the matrix $\mathrm{T}$ and the object, and therefore agreement becomes possible again. The contrast in (53c-d) provides further support for this hypothesis: focalization to the matrix FocP takes the embedded object out of the minimal domain of the embedded $\mathrm{T}$, enabling the embedded object to enter into an agreement relation with the matrix $\mathrm{T}$.

The grammatical status of sentences having the representation in (53) questions the relevance of Chomsky's Activation Condition (Chomsky, 2000), as an integral part of the Agree operation (see also Etxepare, 2006, 2012; Boskovic, 2007). The DP in the Specifier of NegP has already valued its case feature with the embedded T. This does not preclude the object to establish an agreement relation with $\mathrm{T}$ in the matrix clause, reflected in the finite morphology of the auxiliary.

A similar effect arises in the case of adverbial modification: if the object precedes the adverb, agreement becomes possible again (55a).

$$
\begin{array}{lll}
\text { a. Jon-ek behar zituen } & \text { [liburu-ak- } \varnothing_{\text {ABS }} \text { gaur ekarri] } \\
\text { Jon-ERG need AUX.PAST[3plA-3.sgE] } & \text { book-DET.PL-ABS today bring } \\
\text { 'Jon had to bring the books today' } & \\
\text { b. } & \text { Jon-ek behar zituen } & \text { [liburu-ak- } \varnothing_{\text {ABS }} \text { ez ekarri] } \\
\text { Jon-ERG need AUX.PAST[3plA-3.sgE] } & \text { book-DET.PL-ABS not bring } \\
\text { 'Jon had to not bring the books' } &
\end{array}
$$

(55) corresponds to a configuration in which the T head associated to the adverb gaur 'today' does not intervene between the Goal and the matrix T Probe. In that context, agreement is possible.

\section{PERSON VERSUS NUMBER AGREEMENT}

Unlike Number agreement, Person agreement (first and second person) is obligatory, regardless of the relative position of the Goal. In other words, there is no way not to Agree with Person:

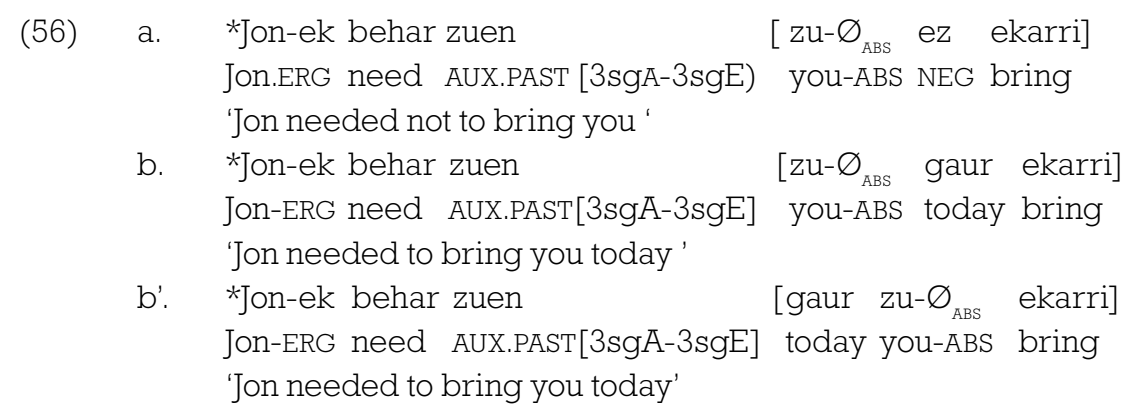


The sentences in $(56 \mathrm{a}, \mathrm{b})$ become acceptable if the matrix auxiliary includes the agreement affixes corresponding to Person:
a. Jon-ek behar zintuen
$\left[\mathrm{zu}-\varnothing_{\mathrm{ABS}}\right.$ ez ekarri]
Jon-ERG need AUX.PAST[2sgA-3sgE] you-ABS NEG bring
'Jon needed not to bring you'
b. Jon-ek behar zintuen [zu- $\varnothing_{A B S}$ gaur ekarri $]$
Jon-ERG need AUX.PAST[2sgA-3sgE] you-ABS today bring
'Jon needed to bring you today'

Why this difference between Number and Person agreement? Our proposal capitalizes on the logic we employed to account for the optionality of Number agreement in the previous cases. This optionality, we argued, is an illusion, one that follows from the fact that the relevant left peripheral elements, like negation and focus, can occupy different positions in the clause structure. When the left peripheral operators dominate Tense, an intervention effect arises, as $\mathrm{T}$ is the closest agreeing head for an argument embedded in the infinitival complement, and it stands on the way of a higher probe (in our cases, the higher matrix auxiliary). The fact that person agreement does not show optionality should, we think, be related to the special status of person agreement when compared to number. We will claim that person agreement is an instance of cliticization.

Etxepare (2006, 2012; see also Preminger, 2009) provides some arguments that person and number agreement obey different locality restrictions in the context of Long Distance Agreement. Under certain configurations, agreement with the object of a nominalized clause is possible in Basque. Consider in this regard the following minimal pair:
a.
$\begin{array}{ll}\text { [Atzerritarr-ak- } \varnothing_{\mathrm{ABS}} & \text { ekartzea] }-\varnothing_{\mathrm{ABS}} \\ \text { Foreigner-DET.PL-ABS } & \text { recruiting-ABS }\end{array}$
baztertu dute
'They declined recruiting foreigners'
b. $\quad\left[\right.$ Atzerritarr-ak- $\varnothing_{\text {ABS }}$ ekartzea $]-\varnothing_{\text {ABS }}$ baztertu dituzte
Foreigner-DET.PL-ABS recruiting-ABS
decline AUx[3sgA-3plE]
baztertu dituzte
decline AUx[3plA-3plE]

'They declined recruiting foreigners'

In (58a), the finite auxiliary shows default third person singular agreement in number for the nominalized clause, its syntactic object. In (57b), the auxiliary shows plural object agreement, that can only correspond to the absolutive object inside the nominalized clause (atzerritarrak 'foreigners'). If the internal object is singular, plural agreement in the finite auxiliary becomes impossible, as shown in (59):

$$
\begin{aligned}
& \text { * }\left[\text { Atzerritar bat- } \varnothing_{\text {ABS }} \text { ekartzea] }-\varnothing_{\text {ABS }}\right. \text { baztertu dituzte } \\
& \text { Foreigner one recruiting-ABS decline AUX[3plA-3plE] } \\
& \text { 'They declined recruiting a foreigner' }
\end{aligned}
$$

Number Long Distance Agreement is possible under certain conditions, which imply the absence of an intervening DP in the embedded nominalized clause, as well as 
conditions related to the expression of embedded Tense ${ }^{7}$. Long Distance Agreement can also target Person, as shown below:

(60) a. Munipa-k- $\varnothing_{\text {ABS }} \quad\left[_{\text {Non-finite }} g u-\varnothing_{\text {ABS }}\right.$ botatzen] saiatu dira

Policeman-DET.PL-ABS us-ABS ousting try AUX[3plA]

'The policemen tried to oust us'

b. Munip-e-k $\quad\left[_{\text {Non-finite }}\left(g u-\varnothing_{\text {ABS }}\right)\right.$ botatzen] saiatu gaituzte

policemen-DET.PL-ERG Us-ABS ousting try AUX[lplA-3plE]

'The policemen tried to oust us'

In (60a), the auxiliary agrees in number with the absolutive subject, and there is no agreement with the nominalized dependent, which is headed by an inessive postposition. In (59b), the finite auxiliary has two agreement indexes: an ergative one, corresponding to the matrix subject munipek 'policemen', and an absolutive one, corresponding to the pronoun $g u$ ' 'us', the object of the non-finite dependent. (60b) constitutes an example of Long Distance Agreement in Person, as the object is not the object of the matrix predicate but of the embedded one.

Etxepare (2012) observes that Person and Number agreement do not have the same distribution. Person agreement is confined to typical restructuring predicates, such as try, manage, decide, or plan. Number agreement is possible with those predicates, but also with non-restructuring predicates. The verb baztertu 'discard' is a case in point $(61 \mathrm{a}, \mathrm{b})$ :

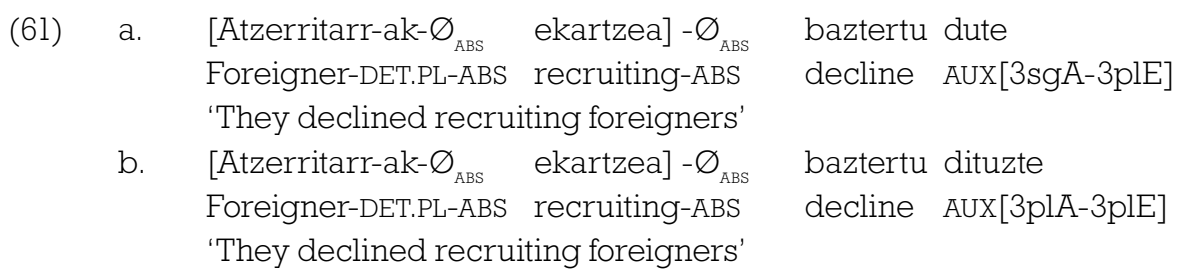

Unlike with a verb like try, Person Long Distance Agreement is not possible with baztertu «discard»:

$$
\begin{aligned}
& \text { *[zu- } \left.\varnothing_{\text {ABS }} \quad \text { ekartzea }\right]-\varnothing_{\text {ABS }} \quad \text { baztertu zaitugu } \\
& \text { you-ABS recruiting-ABS decline AUX[2sgA-lplE] } \\
& \text { 'We discarded recruiting you' }
\end{aligned}
$$

There is nothing in the auxiliary form itself that is wrong (zaitugu is an existing form of the auxiliary paradigm). The crucial factor seems to be the predicate type. Only restructuring predicates allow for Person Long Distance Agreement. Let us note that

7 We refer the reader to Etxepare $(2006,2012)$ and Preminger (2009) for a detailed discussion. 
restructuring predicates are those that allow clitic climbing. Thus intentar 'try' licenses clitic climbing in Spanish, but descartar 'discard' does not:
a. Lo intentamos invitar (lo)
cl-acc tried.lPL invite.inf CL-ACC
'We tried to invite him'
b. *Lo descartamos invitar (lo)
CL-ACC discarded.lPL invite.INF CL-ACC
'We discarded inviting him'

If we stick to restructuring predicates, Person and Number also differ in the following: although Person Long Distance Agreement across several restructuring predicates is possible (64a), Number Long Distance Agreement is not (64b):

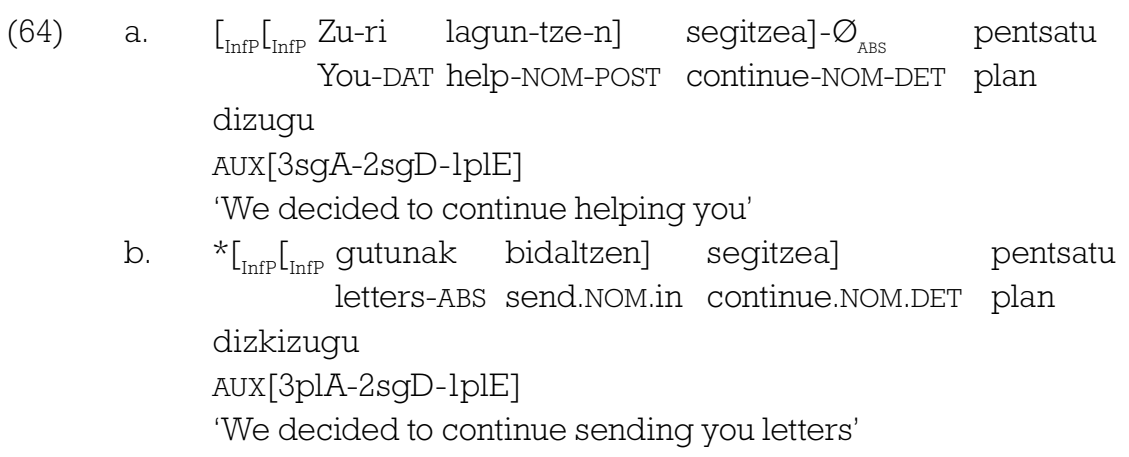

The example in (64a) is reminiscent of clitic climbing in other languages, as in the Spanish (65):

$$
\begin{aligned}
& \text { Te hemos pensado seguir mandando (te) cartas } \\
& \text { CL-DAT have.lPL thought continue-INF sending (CL.DAT) letters } \\
& \text { «We have decided to continue sending you letters» }
\end{aligned}
$$

(64b) on the other hand, includes Number agreement with the embedded object, and this is not possible. In other words, the search domain for the Probe may involve more than one clause in the case of person LDA, but not in the case of Number LDA. Etxepare (2012) claims that this asymmetry is due to the fact that Number agreement is established once and for all in terms of Chomsky's Agree (Chomsky, 2001), and is therefore circumscribed to phasal domains. Person Long Distance Agreement on the other hand, involves movement to the edge of the clause, and can therefore become available to the higher auxiliary. In other words, Person agreement behaves as a special clitic.

There is a further difference between Number and Person agreement in Basque, which points in the same direction. Long Distance Agreement is only possible with the absolutive in Basque. It turns out that Person absolutive agreement in Basque is a morphologically reduced instance of ordinary personal pronouns, unlike Number agreement, which 
has no relation with the pronominal paradigm. The relation between absolutive Person affixes in the auxiliary and pronominal forms is evident from the following simple list ${ }^{8}$ :

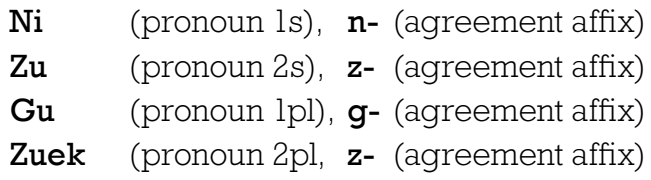

Only in the context of Person Long Distance Agreement can thus we talk about cliticization. If we extend this analysis to the modal configurations, we may obtain a rationale of why Person agreement is obligatory, no matter the position of Negation or Focus. First and Second person clitics establish a syntactic relation with the C-domain, which accounts for why they can cyclically raise into the matrix auxiliary (see San Martin, 2001 for the relation between $\mathrm{C}$ and Person in Basque). Person affixes ( $\mathrm{D}_{\text {Person }}$ in the representation below) cliticize onto the C-T domain (67).

$$
\operatorname{Aux} \ldots\left[\left[_{\mathrm{TP}} \mathrm{D} \mathrm{T}^{\circ} \ldots[\mathrm{rP}, \ldots(\mathrm{D}) \ldots]\right]\right]
$$

From that position it cliticizes onto the matrix auxiliary, where it manifests itself in the form of Person agreement:

$$
\operatorname{Aux}+\mathrm{D} \ldots\left[\left[_{\mathrm{TP}}(\mathrm{D}) \mathrm{T}^{\circ} \ldots\left[\left[_{\mathrm{vP}} \ldots \mathrm{DP}(\mathrm{D}) \ldots\right]\right]\right]\right.
$$

\section{CONCLUSIONS}

A detailed examination of the denominal necessity modal behar in Basque shows two different syntactic configurations: one in which modals precede their non-finite dependents, and one in which they follow them. The latter configurations present properties which correspond to restructuring constructions: absence of left peripheral elements in the dependent, temporal dependencies, transparency for agreement, and rigid ordering in modal stacking. The former present a more flexible syntax: non-finite dependents that follow their modal predicate can be opaque to agreement relations, contain left peripheral elements such as negation or focus, allow independent temporal modification, and permit different ordering alternatives in modal stacking. Our conclusions thus converge with other recent investigations in the area of Basque modal constructions, such as Balza (2018). We have refined and completed some of the earlier work we have done on this issue (Etxepare and Uribe-Etxebarria, 2009), and include a discussion on

8 The relation between $z u e k$ and $z$ - is perhaps not inmediately evident. But $z u e k$ as the second person plural pronominal is a recent addition to the Basque pronominal paradigm. It is a complex form, composed of $z u$ 'you', the ancient 2 person plural pronoun, and the demonstrative bek «those». The construct replaced the plural $z u$, originally the second person plural pronoun that evolved into a polite singular form (Manterola, 2015). The form to which the affix should be compared is thus $z u$. 
the different status of Number and Person agreement in the context of modal predicates. We have reached the conclusion, in line with previous similar claims by Etxepare (2006, 2012), that absolutive Person agreement, unlike Number agreement generally, is a manifestation of clitic climbing to the C-T domain. Our discussion also establishes that the so-called Activation Condition (Chomsky, 2000), relating agreement and Case checking in a single operation, cannot be sustained (see also Bhatt, 2005; Etxepare, 2006; Boskovic, 2007; and Saito, 2016).

\section{REFERENCES}

Alzola, N. (1994). Euskaraz Irunen barrena. Irun: Luma.

Arregi, K. (2001). Focus and Word order in Basque (ms). Massachussetts Institute of Technology (MIT).

Arregi, K. \& Nevins, A. (2012). Morphotactics: Basque Auxiliaries and the Structure of Spell Out. Dordrecht: Springer.

Balza, I. (2010). Clausal architecture and morpho-syntactic structure from the point of view of modal verbs (ms). University of the Basque Country (UPV-EHU).

Balza, I. (2018). Syntactic Structure and Modal Interpretation. The Case of Basque Behar (doctoral dissertation). University of the Basque Country (UPV-EHU) \& Université Bordeaux Montaigne.

Belletti, A. (2005). Extended doubling and the VP periphery. Probus, 17(1), 1-36.

Bhatt, R. (2005). Long Distance Agreement in Hindi-Urdu. Natural Language and Linguistic Theory, 23, 757-807.

Boskovic, Ž. (2007). On the locality and motivation of Move and Agree: an even more minimal theory. Linguistic Inquiry, 38, 589-644.

Chomsky, N. (2000). Minimalist inquiries: the framework. In R. Martin, D. Michaels \& J. Uriagereka (eds.), Step by step: essays on a minimalist syntax in honor of Howard Lasnik (p. 89-155). Cambridge: MIT Press.

Chomsky, N. (2001). Derivation by Phase. In M. Kenstovicz (ed.), Ken Hale: A Life in Language (p. 1-54). Cambridge, MA: MIT Press.

Chomsky, N. (2013). Problems of projection. Lingua, 130, 33-49.

Cinque, G. (1999). Adverbs and Functional Heads. A Cross-Linguistic Perspective. Oxford: Oxford University Press.

Den Dikken, M. (2006). Relators and Linkers: The Syntax of Predication, Predicate Inversion, and Copulas. Cambridge: MIT Press.

Etxepare, R. (2006). Number Long Distance Agreement in (Substandard) Basque. In J. Lakarra \& J. I. Hualde (eds.), Studies in Basque and Historical Linguistics in Memory of R. L. Trask. Anuario del Seminario de Filologia Vasca "Julio de Urquijo", 40, 1-2, 303-350.

Etxepare, R. (2012). Agreement configurations. Lessons from distance (Thèse d'habilitation). Université Bordeaux-Montaigne.

Etxepare, R. (2016). PF conditions on Basque focus-verb adjacency. In J. Fernandez-Vest \& R. van Valin (eds.), Crosslinguistic studies in Information Structure (p. 122-147). Berlin: Mouton. 
Etxepare, R. \& Haddican, B. (2017). Repairing Final-Over-Final Constraint Violations: Evidence from Basque Verbal Clusters. In L. Bailey \& M. Sheehan (eds.), Order and Structure in Syntax I. Word Order and Syntactic Stucture (p. 135-157). Berlin: Language Science Press.

Etxepare, R. \& Uribe-Etxebarria, M. (2008). On negation and focus in Spanish and Basque. In X. Artiagoitia \& J. Lakarra (eds.), Gramatika Jaietan. Patxi Goenagaren Omenez (p. 287-310). Bilbao: University of the Basque Country, UPV/EHU.

Etxepare, R. \& Uribe-Etxebarria, M. (2009). Hitz hurrenkera eta birregituraketa euskaraz. In R. Etxepare, R. Gómez \& J. Lakarra (eds.), Beñat Oihartzabali Gorazarre. Festschrift for Bernard Oyharçabal. International Journal of Basque Linguistics and Philology, 43(1-2), 335-356.

Etxepare, R. \& Uribe-Etxebarria, M. (2012). Denominal necessity modals in Basque. In U. Etxeberria, R. Etxepare \& M. Uribe-Etxebarria (eds.), Noun Phrases and Nominalizations in Basque. Syntax and Semantics (p. 283-332). Amsterdam: John Benjamins.

Fernández, B. (2001). Absolutibo komunztaduradun ergatiboak, absolutibo komunztaduradun datiboak: ergatiboaren lekualdatzetik datiboaren lekualdatzera. In P. Albizu \& B. Fernández (eds.), Kasua eta Komunztaduraren Gainean. On Case and Agreement (p. 147-166). Bilbao: Euskal Herriko Unibertsitatearen Argitalpen Zerbitzua.

Haddican, W. (2004). Sentence Polarity and Word Order in Basque. The Linguistic Review, 21(2), 81-124.

Haddican, W. (2005). Aspects of Language Variation and Change in Contemporary Basque (doctoral dissertation). New York University (NYU).

Haddican, W. (2008). Euskal perpausaren oinarrizko espez-buru-osagarri hurrenkeraren aldeko argudio batzuk. In I. Arteatx, X. Artiagoitia \& A. Elordieta (eds.), Antisimetriaren hipotesia vs. Buru parametroa: euskararen oinarrizko bitz hurrenkera ezbaian (p. 69-96). Bilbao: University of the Basque Country (UPV/EHU).

Hansen, B. \& De Haan, F. (eds.) (2009). Modals in the Languages of Europe. Berlin: Mouton de Gruyter.

Irurtzun, A. (2007). The Grammar of Focus at the Interfaces (doctoral dissertation). University of the Basque Country (UPV/EHU).

Harves, S. \& Kayne, R. S. (2012). Having 'Need' and Needing 'Have'. Linguistic Inquiry, 43(1), 120-132.

Kerrain, M. (2010). Le Guide du bretonnant. Pornizh: An Amzer.

Laka, I. (1990). Negation in Syntax. On the Nature of Functional Categories and Projections (doctoral dissertation). Massachusetts Institute of Technology (MIT).

Manterola, J. (2015). Euskararen morfologia historikorako: artikuluak eta erakusleak (doctoral dissertation). University of the Basque Country (UPV/EHU).

Moro, A. (2001). Dynamic Antisymmetry. Cambridge: MIT PRESS.

Ormazabal, J. \& Romero, J. (2007). The Object Agreement Constraint. Natural Language and Linguistic Theory, 25, 315-347.

Preminger, O. (2009). Breaking Agreements. Linguistic Inquiry, 40(4), 615-666. 
Ramchand, G. \& Svenonious, P. (2014). Deriving the functional hierarchy. Language Sciences, 46, 152-173.

Rezac, M. (2016). Gaps and stopgaps in Basque finite verb agreement. In B. Fernández \& J. Ortiz de Urbina (eds.), Microparameters in the Grammar of Basque (p. 138-194). Amsterdam/Philadelphia: John Benjamins. (Language Faculty and Beyond, 13).

Saito, M. (2016). (A) Case for Labeling: Labeling in Languages without Phi-Feature Agreement. The Linguistic Review, 33, 129-179.

San Martin, I. (2001). On Subordination and the Distribution of PRO. Doctoral dissertation, University of Maryland.

414 Fontes Linguae Vasconum (FLV), 126, julio-diciembre, 2018, 389-414

ISSN: 0046-435X ISSN-e: 2530-5832 